\title{
自閉症における言語・行動
}

\author{
白瀧 貞昭
}

要 約: 今日, 自閉症は幼児早期 ( 3 歳頃までに) 発症し，人との社会的関係の障害，コミ ユニケーションの障害(単なる言語の障害ではない), 常同的で固執的な興味や行動様式といっ た特徵を有する発達障害と定義される。 その原因に関して, 脳の器質的障害が疑われているが, 現在のところその実体は不明である．自閉症のような発達期の障害が脳障害を原因として持つ としても，両者の関係は決してストレートなものではない. 自閉症行動から直ちに原因を明ら かにできるほどわれわれの知識は十分でない.

特に, 言語障害の内容に重点を置き, 現在までに明らかになっている自閉症の諸症状を整理 し，それらの構造を示した．そして，自閉症児の中でも数少ない，高発達を示した年長自閉症 者の 1 例を紹介した。最後に, 発達初期の母子関係の確立に焦点を当てた自閉症児への療育, あるいは, 社会性発達のための療育の理念を紹介した。

索引用語：自閉症, 脳器質障害, 社会性発達障害, 言語障害, 母子関係

\section{Language and Behavior in Autistic Disordered Children}

\section{Sadaaki Shirataki}

\begin{abstract}
The autistic disorder is defined today as follows: 1) all symptoms manifest before 36 months of age, 2 ) social relationships with other peers or adults are qualitatively impaired, 3 ) verbal and nonverbal communication, and imaginative activity are qualitatively impaired, and 4 ) repertoires of activities and interests are markedly restricted. The author discussed about etiological aspect of the autistic disorder. A brain organic impairment is speculated as the cause of this disorder, but the conclusive elusidation is yet to be done. Even if a brain impairment is existing in the brain of the autistic disordered children, the relationship between the brain impairment and the resulting behavioral symptoms should not be straightforward.

In the next, various kind of behavioral symptoms of the autistic disorder are described, and the core structure of the symptoms is elusidated, paying special attention to the language problems.

Further, one adult case of the autistic disorder who showed very difficult social adjustment, contrasting rather high intellectual development is reported to illustrate how the autistic disordered lives.

Finally, a guideline for the therapy of the autistic disordered child is discussed, in which the establishment of attachment relationship in early infancy between the infant and the mother was specifically stressed.
\end{abstract}


Key words : Autistic disordered child, brain organic impairment, impairment of social development, language impairment, mother-infant relations

\section{はじめに}

今日，自閉症は 1) 幼児早期（3歳頃まで）に発症 し，2）社会関係の障害（単なる遅れではない，３） コミュニケーションの障害（単なる言語の遅れではな い)，4）常同的あるいは制限された行動様式，といっ た特徵を持つ発達障害と定義される ${ }^{1)}$ (表 1 ). 自閉症 児が有する行動特徴については，今日までにほぼ言い 尽くされているといってよいであろう。しかし，1つ の疾患単位として，はっきりと他の疾患から区別する ことが可能なのか否か, 類似の行動特性を示す精神発 達遅滞とどのように異なるのか, その原因は何なのか, どのような治療, 訓練法が有効なのかなど，まだまだ 解明されていない問題も多いのである。自閉症が脳障 害を原因として生じるのであるとの見解は最近，とみ に目にすることが多いのであるが，少なくともこのシ ンポジウムの他のテーマと比べて, 自閉症は最も脳障 害との関係が不確かなのではないかと思われる。自閉 症が脳の器質的障害に基づくという仮説は, 現在なお 慎重な吟味を要する物であると筆者は考えている2).

そこで，まずはじめに，そもそも小児における脳障 害と行動との間の関連についてどのような特徵がある のかを考え, 次いで, 自閉症と脳障害との関連に関し て, 現時点で考え得るモデルを提出してみたい. 次に, 今日までに明らかにされている自閉症の行動特徵を示 し，特に言語面の障害について詳しく示したい，自閉 症が単に幼児期の問題にとどまらず，青年期，成人期 に至るまで持続するものであることは, 既に過去の経 験から明らかであり，それだけ予後の難しい障害であ るのであるが，中には成人期に至るまでにかなり高い 発達を示す症例がある。このような症例を具体的に示 し，最後に自閉症全般について望ましい療育，訓練の あり方について触れることにする。

\section{I 、発達期の中枢神経系，およびその 行動関連の特徵（表 2 , 表 3 )}

小児における脳障害と行動（異常な）との関連を考 えるに当って，われわれはつねに成人における両者の 関連のあり方をモデルとしてきたといってよいであろ う。しかし，今や，小児の発達中の脳と成人の脳とは まったく質を異にするという認識が，少なくとも理念 的には大方の人によって共有されるようになったと言 ってよい. 異常発達中の脳であれ, 正常発達中の脳で あれ，それと行動との関連は発達中の脳それ自体の独 自性において考えられねばならないはずである。事実, 例えば, 成人の脳障害の結果として出現する失語症と 小児におけるそれとは現れ方が異なるのだという報告 がある ${ }^{3)}$.さらに言えば, 発達期の脳障害一般と失語症 との関連を問うことさえ不十分であり, 発達期の脳で もどの発達段階の脳と規定しなければ，決して正確な 障害脳と失語症との関連は明らかにならないのであ る.

ここで強調したいことは, われわれはまず発達段階 ごとにその特質を変えていく脳発達のダイナミズムを 理解すること, その次に, 障害された脳が発達してい く中で, どのような行動特性を出現させていくのかを 知ることができて, その後に初めて言葉の障害, 行動 の異常, 注意の無さなどの症状からその背景にある疾 患を知り，さらに，この疾患を生んでいる脳の障害部 位を特定できるかもしれないということである，現時 点でこれらのプロセスがまだまだ不十分であるにもか かわらず，われわれは症状群からこれらを生じさせて いる脸の障害部位を特定してしまおうとあせっている ように思われる。

表 2 には正常発達中の脳の特性と, 脳一行動連関の 特徴を示した。ささらに, 表 3 には異常発達中のそれを

表 1 自閉症の診断基準

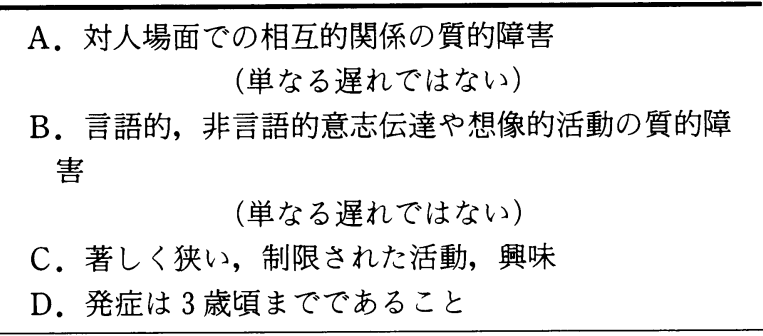

(DSM III-Rによる) 
表 2 発達中の中枢神経系 (CNS) の特徵一発達神経学的観点一

\begin{tabular}{|c|c|c|}
\hline $\begin{array}{l}\text { I. 発達中のCNS は成人のそ } \\
\text { れのミニチュア版ではない. 各発 } \\
\text { 達段階に特異的な構造と機能を有 } \\
\text { しつつ常に変換されていく動的プ } \\
\text { ロセスを示す. }\end{array}$ & $\begin{array}{l}\text { II. より低次 (末梢) から高次(中 } \\
\text { 枢)の構造・機能へと常に一直線 } \\
\text { 的, 加算的に積み重ねられていく } \\
\text { のではない. }\end{array}$ & $\begin{array}{l}\text { III. CNSの各パートはび漫性に } \\
\text { 一様に成熟するのではなく, 環境 } \\
\text { からの要請に従ってそれぞれ異な } \\
\text { ったタイミングで成熟していく. }\end{array}$ \\
\hline $\begin{array}{c}\text { ある発達段階にしか存在しない } \\
\text { 神経機構がある. } \\
\text { ・神経細胞死, 一過性のシ } \\
\text { ナップス結合 } \\
\text { ・ある発達段階にしか見られな } \\
\text { い神経機構がある. } \\
\text { ・胎児・新生児の運動パ夕 } \\
\text { ーン } \\
\text { (老人にみられる原始反射 } \\
\text { は新生児のそれとは同一 } \\
\text { でない) } \\
\text { ・したがって, 各段階でのCNS } \\
\text { 評価のためには段階特異的評 } \\
\text { 価法の工夫が必要となる. }\end{array}$ & $\begin{array}{c}\text { •ある段階から逆により低次の段 } \\
\text { 階へと退行することがある. } \\
\text { また, ある時期に一時消失し } \\
\text { てしまうこともある. } \\
\text { ・ある感覚一運動機構の完 } \\
\text { 全な消失 } \\
\text { ・ある感覚一運動機構によ } \\
\text { って抑えられる (原始反 } \\
\text { 射) } \\
\text { ・ある感覚系が別の感覚系 } \\
\text { に置き換えられ, この系 } \\
\text { を通じて同じ運動が生起 } \\
\text { する (直立姿勢維持のた } \\
\text { めの視覚系と前庭系の役 } \\
\text { 割交替). } \\
\text { ・感覚系は変わらないのに } \\
\text { 別の運動系と結びつけら } \\
\text { れてしまう（随意的手指 } \\
\text { 把握). } \\
\text { ・ } 2 \text { つの神経機構が互いに } \\
\text { 競合しながら発達する. }\end{array}$ & 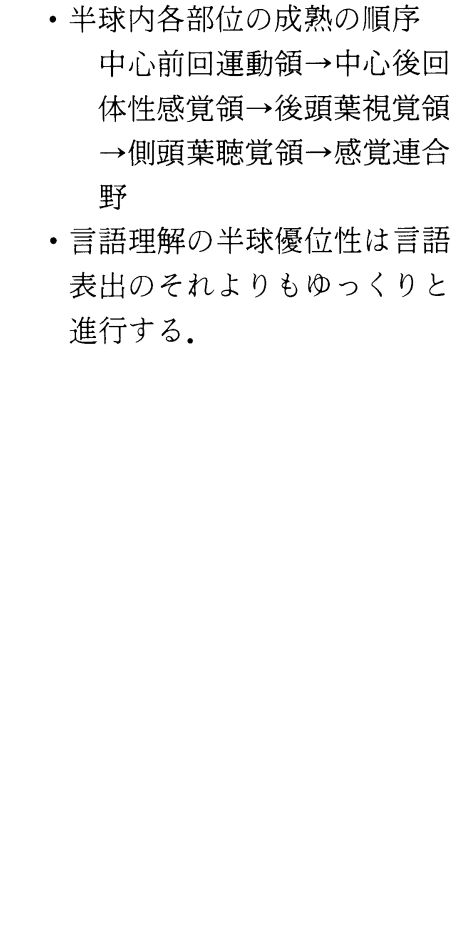 \\
\hline
\end{tabular}

（文献 2 ) より引用）

示した。これらの中には従来の認識とは大いに異なる ものがあることに注意する必要がある。

\section{II. 自閉症における脳一行動（自 閉症性行動）連関モデル}

自閉症の原因としての脳器質障害説には，なお慎重 な吟味が必要であると既に述べたが，今までに自閉症 児の脳障害が明らかにされているわけではないし，先 天的，あるいは生下時の脳障害が単純に自閉症を作る とする考えは, 発達が生下時に与えられた個体特性と, その後の環境特性の両方によって規定されるという大 原則 ${ }^{4}$ を無視するという意味においてもきわめて単純 すぎると言えよう。仮に発達の初期に脳障害があって も, 後の環境特性にそれを代償するような要素があれ ば，必ずしも発達そのものが障害されるとは限らない
というのが実際のところである。そこで，個体特性と しての脳特性（粗大な障害が初めからあって，そのた めに後に自閉症に至ることは非常に稀であり，大概は 脳機能の脆弱性のみを示すような）とハイリスク環境 の両方の交互作用の結果, 自閉症が生成されると考え るのが妥当であろうと思われる。このことを図 1 に示 した.

\section{III。自閉症における行動間（症状群）構造(表 4)}

自閉症についてのわれわれの課題は，それを特徵ず ける行動群から直ちにそれを出現させている脳の障害 部位を特定することではなく, 行動群を整理して, 自 閉症に特異的なもの，二次的に派生したもの，あるい は, 自閉症児の発達に伴って変化していくものとそう でないものなどを明らかにしていくことである。この 
表 3 異常発達中の中枢神経系 $(\mathrm{CNS})$ の特徴 - 発達神経学的観点一

I 、異常発達をしている CNS か ら出現する徵候もまた発達段階特 異性を有する。

・新生児期に見られる過興奮症 状群 (hyperexcitabilty syndrome）は生後 $3 \sim 4$ 力月ま でしか見られず，その後消失 する。しかし，潜伏期間を経 て学童期になって舞踏病様ジ スキネシア (choreiform dyskinesia)として出現する.

・学童期に見られる不器用さ (clumsiness) は乳幼児期か ら連続的に出現しているので はない.

- 大脳皮質の一次, 二次, 三次 領のうち, 一次領に損傷が加 わった場合，上位の二次，三 次領の機能が安定していない ために直ちに二次, 三次領全 体の機能異常を引起こしてし まう。また，限局した大脳病 変であっても, その後完成し ていくはずの機能の構造化, 体制化に発達に伴う“ひずみ” をもたらす。
II. 異常発達をしている CNS か ら出現する運動パターンは退行も 非連続性も示さず，始終常同的で ある。

・外界からの多様な要請に応え ることができず常に同一の, そして不適切な行動パターン で対応してしまう。

・外界からの要請に応えて最も 適切な行動パターンを試行錯 誤によって見つけだすまでに 長い時間を要する。

-外界からの要請に対して, 結 局，適切な答を見つけること ができない.

- 外界からの要請に対して, や つと見つけた答え（行動パ夕 ーン）が不適切であっても， それを認める能力が低下して いる.
III. 異常発達中の CNS は成人の 障害 CNS に比して可塑性が大で あるとはいえ，それによって正常 な CNS の発達が約束されるもの では決してない.

・むしろ発達初期の脳における 損傷の方が後の行動発達に及 ぼす悪影響は大である。この 意味でも微細脳機能障害 (Minor Brain Dysfunction) という概念は不正確で ある。

•CNS の発達が最も盛んな部位 が最も外因に対して脆弱であ る(ドッビング (Dobbing) の 易傷性 (vulnerability))。発達 のスピードは各部位によって 異なるから, 同じ脳でも部位 によって選択的に脆弱性が異 なることになる。

(文献 2 ) 上り引用)

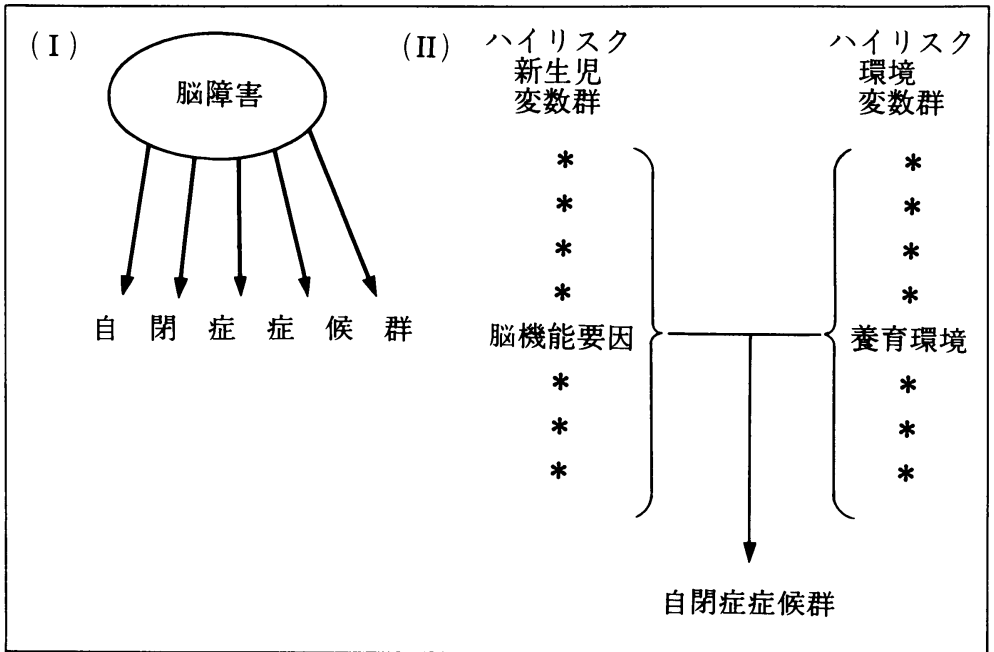

図 1 自閉症（症候群）の発生モデル 
ことにより，ただの症状の羅列ではなく，症状群の中 に含まれる自閉症特有の構造を把握することができる のではないかと考えられる。一般に自閉症状とされる 行動は異なった発達段階に応じて変化していく, 異な った機能レベルの行動が混同されて，秩序なく並べら れているにすぎないのである。これを整理して，これ らの行動間にある構造を明らかにしたのが表 4 に示さ れている.

\section{IV 、自閉症における障害の種類}

今日,自閉症の基本的障害として既に述べたように， 対人関係障害, コミュニケーション障害, 同一性への 固執が重視されているが，アメリカの精神障害分類 (DSM-III-R $)^{1)}$ に従って，それぞれの範疇の中でどの ような障害が見られるかを示してみる．表 5 には対人 場面での相互関係の質的障害, 表 6 には言語的, 非言

表 4 自閉症における行動間（症状群）構造

\begin{tabular}{c|l|l|l}
\hline 月 & \multicolumn{1}{|c|}{ レベル I } & \multicolumn{1}{|c|}{ レベル II } & \multicolumn{1}{|c}{ レベルIII } \\
\hline 0 & $\begin{array}{l}\text { 障害された姿勢制御系 } \\
\text { (disordered postural control } \\
3 \\
\text { system) }\end{array}$ & $\begin{array}{l}\text { 障害された “生理的状態” の } \\
\text { 組 織 化 (disordered states } \\
\text { organization) }\end{array}$ & $\begin{array}{l}\text { 障害された愛着行動 } \\
\text { (disordered attachment } \\
\text { behavior) }\end{array}$ \\
\hline 3 & $\begin{array}{l}\text { 障害された手の使用 } \\
\text { (disordered manual usage) }\end{array}$ & $\begin{array}{l}\text { 障害された目-手の協応 } \\
\text { (disordered eye-hand coor- } \\
\text { dination) }\end{array}$ & $\begin{array}{l}\text { 障害された母子相互作用 } \\
\text { (disordered infant-mother } \\
\text { interaction) }\end{array}$ \\
\hline 8 & $\begin{array}{l}\text { 障害された行動の統合 } \\
\text { (disordered behavioral inte- } \\
\text { gration) }\end{array}$ & $\begin{array}{l}\text { 障害された聴覚性理解 } \\
\text { (disordered auditory com- } \\
\text { prehension) }\end{array}$ & $\begin{array}{l}\text { 障害された言葉でのコミュニ } \\
\text { ケーション } \\
\text { (disordered verbal commu- } \\
\text { nication) }\end{array}$ \\
\hline $\begin{array}{l}18 \\
36\end{array}$ & $\begin{array}{l}\text { 障害された行動の統合 } \\
\text { (disordered behavioral inte- } \\
\text { gration) }\end{array}$ & $\begin{array}{l}\text { 障害された感覚間統合 } \\
\text { (disordered intersensory } \\
\text { integration) }\end{array}$ & $\begin{array}{l}\text { 障害された社会的相互作用 } \\
\text { (disordered social interac- } \\
\text { tion) }\end{array}$ \\
\hline
\end{tabular}

(文献 2 ) より引用)

表 5 自閉症の症状 ( 1 )

A. 対人場面での相互的関係の質的障害

1.他者の存在, 感情に気づく能力欠如

2. 苦しい時に安楽を求めることができない

3. 模倣の不足, 欠如

4 . 社会性の要る遊びの欠如, または異常

5.仲間関係を作る能力の著しい不足

（文献 1 ) より引用）

表 6 自閉症の症状 ( 2)

B. 言語的, 非言語的意志伝達や想像的活動の質的障害

1.喃語, 表情, 身振り, 物真似, 話し言葉などの伝達様式の欠如

2. 対人場面での相互的関係を開始, 調節することでの著しい障害

3.想像的活動の欠如

4.会話の様式の著しい障害（音量, リズム, 抑揚)

5.常同的, 反覆性の言語の使用

6. 適切な会話ができるのに, 会話を始めたり, 継続する能力の著しい障害

（文献 1 ）より引用） 
表 7 自閉症の症状 ( 3 )

C. 著しく狭い, 制限された活動, 興味

1.常同的身体運動（頭を打ちつけるなど）

2.対象物の部分へのとらわれ, 固執, 特殊な事物への愛着

3. 環境の些細な面の変化にさえ抵抗する

4. 同一性への強迫的固執

5. 常同的, 限局的興味のパターン

(文献 1 ) より引用)

表 8 自閉症の言語障害

1.言語発達の遅れ

始語の遅れ

$1 / 5$ で数語の獲得後消失する

2 .話し言葉の獲得の障害

・約半数は全く言葉を獲得しない

・少数はほとんど平均レベルの言葉を獲得する

3.即時性反響言語

・ほとんどの自閉症児でみられる

・しかし, 自閉症に特異的ではない

4 . 遅廷性反響言語

5. 一人称, 二人称の使い分けの障害

- 自閉症に特異的

6.話し言語の障害を他のジェスチュア, 顔の表現, 模倣などに

よって代償できない

7.仮に流暢に話せても，相手と会話が成立しない

Semantic-pragmatic syndrome(Rapin and Allen, 1983)

語的意志伝達や想像的活動の質的障害, 表 7 には著し く狭い, 制限された活動, 興味についての諸障害が列 記されている。ささら，表 8 には自閉症における言語 障害の詳細について示した。ここで示されているよう に, 言語を含む象徵幾能全般の障害であると言える. なお, $\operatorname{Rapin}^{5)}$ が言語学の立場から自閉症の言語障害を semantic-pragmatic syndrome という言葉でまとめ ているが，文法的にも，意味的にも正しい文章であり ながら, 普通の対人場面では聞かないようなあまりに も個人的な事柄とか, 突拍子もない事柄を含む文章が 自閉症児に特異的に用いられるのをわれわれはよく観 察するのである。

\section{V．年長自閉症者の症例}

ここで，理解を容易にするために実際の症例を紹介 することにする．表 9 にその概略を示したが, この症 例は知的にはかなり高度の発達を獲得した例である。
それにもかかわらず，対人関係を多く含む集団生活場 面での適応は非常に悪く, 言語発達面でも会話はほほ 普通にできるにもかかわらず，一方的な話題設定であ ったり，相手のあまりにもプライベートなことを聞い たりで, 相手の気持ちを思いやるということに困難を 感じている様子がありありと見てとれる。このような ケースこそ自閉症の典型とも言えるものであるが，数 として圧倒的に多いのは知的発達遅滞を伴う自閉症で ある. 知的発達遅滞を伴う自閉症児（者）の示す障害 のなかには, 本来, 自閉症に本質的な障害だけでなく, 知的発達遅滞に起因する障害が含まれる可能性があ り，これを誤って自閉症性の障害としてしまってはな らないのである。

\section{VI. 自閉症児 (者) の療育, 訓練}

当然, 療育の方法は自閉症の原因として何を想定し ているかによって異なってくるであろう。筆者は, 生 
表 9 症例

T. S.（令）27歳, 公立共同作業所通所中.

[家族歴] 父 62歳, 元教師, 現在アルコール性脳 症のため入院中, 母 61 歳, 主婦, と本人の 3 人家族.

[生育歴] 父 35歳, 母34歳の時に一人っ子とし て出生.母出産前に 3 年間腰椎カリエスのために入 院治療. 本人は満期なるも「さかご」, 臍帯てん絡の状 態にて出生. 乳児期は発育良好. 始語, 始歩もむしろ 平均よりも早目であった。 2 年間保育所に通ったが, 一人遊びが多かったという。 5 歳前には簡単な文章も しゃべっていた。しかし，この時期に自閉症と診断さ れていた。

普通小学校に入学するも出席状況は悪く, 授業時間 中にも外へ逃げだしたり，登校をしぶることがよくあ った，文字の習得はほほ平均レベルにできていた。

普通中学校に入学するが, 成績は劣悪で, 無断でよ く教室を飛び出したりした。

中学卒業後, しばらく在宅となるも, 母が父と姑と の折り合いが悪く, 別居となり, 本人は祖母に育てら れる. その後, 共同作業所に知合いのこねで入れても らうも，本人は精薄の療育手帳を持っていないことを ひけめに感じだし, 自分を早く, 精薄と認めてもらい たいと願うようになった。社会性は劣り，作業所への 適応も困難であった，会話がある程度できるが，話題 は常に自分で決めたものでなければならない. TIQ: 94 (PIQ: 90, VIQ: 96).

後間もない時期から母子間に成立すべき愛着関係の確 立が子供側, あるいは母親側の要因によって阻害され るのではないかと想定する。 そして, 愛着関係を通じ て形成されるべき対人, 対社会性, 認知機能等がうま く形成されないのだろうと考えている.重要なことは, これらの機能が最初の 1 年間の母親への完全な依存の 中で形成されるということである.

そこで, 年少自閉症児の場合には, 療育はこの母子 愛着関係の確立のために必要なあらゆる手立てをとる ことに向けられる．いわば，正常の乳児の場合には， 自然に進行する愛着関係確立プロセスを意識的に作り 上げると言えるかもしれない。何よりも，この母子関 係を土台にして他の大人との関係が成立し，その後で はじめて同年代の子供同志の関係が成立する（3 歳以 後）のが正常の発達コースなので, 自閉症児の場合に もこの発達にのっとって療育を進めることになる．表 10 にはこの面での発達目標を示した。

表 11 に Rutter ${ }^{6}$ が自閉症児の社会性発達の障害に 対してどのようにアプローチするかを理念的に示して
表10 自閉症年少時期における発達目標

1.母親との 1 対 1 関係の確立

2. 園での複数の大人との関係の確立

3. 大人によって媒介される子供同士の集団関係の 確立

4. 子供同士の集団関係の確立

表11 自閉症の療育一社会性発達の促進 自閉症児の持つ

必要なポイント 問題解決法

1. 楽しく反応し 社会的場面での構 合う対人関係を一対社会関係の欠如一造化された相互作 濃密に持つ 用 反応性の欠如

2.個別的養育_—施設で養育して_乳幼児期には収容 しまう一施設に入れない

3. 社会的認知——障害——社会技能などを直 能力 接教示する

Rutter, M. (1985) による

いるので引用した。

ここで，大切なことは自閉症児の言語面の障害がい かに重要であるとしても，ただ言語の訓練をすれば良 いというものではないということである。明らかに障 害されているものは, 人との関係をもつための手段と しての言語だけではなく，人と関係をもつことそのも のである、だから, 既に述べたように言語以外の非言 語的コミュニケーションにも障害が認められる。自閉 症児を取り巻く人環境が, 自閉症児にとって役に立つ, 好ましいものであることの認識をいかに持たせるかが 療育の要点であるように思われる。

\section{文献}

1) American Psychiatric Association: Diagnostic and Statistical Manual of Mental Disorders (Third Edition-Revised). DSM-III-R., 1987.

2) 白瀧貞昭: 自閉症の発達神経心理学的研究. 自閉 症の研究と展望, 山崎晃資, 栗田広編, 東京大学 出版会, 197-217, 1987.

3) Hecaen, H. : Acquired aphasia in children. Brain and Language, $3: 114-134,1976$.

4) Sameroff, A. J. : Early influences on development : fact or fancy? Merrill-Palmer Quarter- 
ly of Behavior and Development, $21: 267-294$, 1975.

5) Rapin, I. and Allen, D. : Developmental language disorders : nosologic considerations. In : Neuropsychology of Language, Reading, and Spelling. U. Kirk (ed.), N. Y., Academic Press, 155-184, 1983.
6) Rutter, M. : The treatment of autistic children. J. Child Psychol. Psychiat. 26 : 193-214, 1985.

別刷請求先： 650 神戸市中央区楠町 7 神戸大学医学部精神神経科学教室 白瀧貞昭 